Article

\title{
Interaction between Sex and LDLR rs688 Polymorphism on Hyperlipidemia among Taiwan Biobank Adult Participants
}

\author{
Yin-Tso Liu ${ }^{1,2}{ }^{\text {, Oswald Ndi Nfor }}{ }^{3}$, Lee Wang ${ }^{3}$, Shu-Yi Hsu ${ }^{3}$, Chia-Chi Lung ${ }^{3}$, \\ Disline Manli Tantoh ${ }^{3}(\mathrm{D})$, Min-Chen Wu ${ }^{4}$, Horng-Rong Chang ${ }^{1,5, *}$ and Yung-Po Liaw ${ }^{3,6, *(\mathbb{D})}$ \\ 1 School of Medicine, Chung Shan Medical University, Taichung 40201, Taiwan; cvsliu0325@gmail.com \\ 2 Department of Cardiovascular Surgery, Asia University Hospital, Taichung 40201, Taiwan \\ 3 Department of Public Health and Institute of Public Health, Chung Shan Medical University, \\ Taichung 40201, Taiwan; nforoswald2@yahoo.com (O.N.N); w1@csmu.edu.tw (L.W.); \\ sui0209@gmail.com (S.-Y.H.); dinoljc@csmu.edu.tw (C.-C.L.); tantohdisline@yahoo.com (D.M.T.) \\ Office of Physical Education, Chung Yuan Christian University, Taoyuan 32023, Taiwan; \\ minchen@cycu.edu.tw \\ 5 Division of Nephrology, Department of Internal Medicine, Chung Shan Medical University Hospital, \\ Taichung 40201, Taiwan \\ 6 Department of Medical Imaging, Chung Shan Medical University Hospital, Taichung City 40201, Taiwan \\ * Correspondence: chrcsmu@gmail.com (H.-R.C.); liawyp@csmu.edu.tw (Y.-P.L.); \\ Tel.: +886-424-730-022 (ext. 11838) (H.-R.C.); Fax: +886-423-248-179 (Y.-P.L.)
}

Received: 20 December 2019; Accepted: 3 February 2020; Published: 5 February 2020

\begin{abstract}
Hyperlipidemia is one of the strong risk factors for ischemic heart disease. Using the Taiwan Biobank (TWB) database, we evaluated the risk of hyperlipidemia and its interaction with sex and rs688 polymorphism on the low-density lipoprotein receptor (LDLR) gene. Data collection in the biobank started in 2008 and is ongoing. Data analysis was performed on the participants' data collected between 2008 and 2015. In general, $27.92 \%$ of the 9237 female participants and $32.65 \%$ of the 8690 male participants were identified with hyperlipidemia. Compared to the $C / C$ genotype, $C / T$ and $\mathrm{T} / \mathrm{T}$ genotypes were not significant risk factors for hyperlipidemia $(\mathrm{OR}=1.061, \mathrm{CI}$ : $0.976-1.153$ for $\mathrm{C} / \mathrm{T}$ and OR $=1.052$, CI: $0.845-1.309$ for T/T genotype) in the general model. However, there was a significant interaction between sex and rs6888 on hyperlipidemia risk (p-interaction $=0.0321$ ). With the male sex/CC genotype being the reference group, only the female sex/CT and $\mathrm{T} / \mathrm{T}$ genotypes were closely associated with hyperlipidemia, with respective ORs of 1.153 (CI: 1.014-1.311) and 1.423 (CI: 1.056-1.917). Our data indicate that $\mathrm{rs} 688 \mathrm{C} / \mathrm{T}$ and $\mathrm{T} / \mathrm{T}$ genotypes may be associated with increased risk of hyperlipidemia in Taiwanese women. These findings may be relevant in lipid-modification therapy.
\end{abstract}

Keywords: hyperlipidemia; sex; biobank; polymorphism

\section{Introduction}

Hyperlipidemia, defined as elevated total cholesterol (TC $\geq 240 \mathrm{mg} / \mathrm{dL}$ ), elevated triglyceride (TG $\geq$ $200 \mathrm{mg} / \mathrm{dL}$ ), or both, is a well-established risk factor for atherosclerosis, which is closely associated with cardiovascular diseases (CVD) [1,2]. The rates of hyperlipidemia differ with gender, age, socioeconomic status, and ethnicity, and have increased tremendously in the Asia Pacific region over the past decade [3]. This increase in the prevalence of hyperlipidemia has contributed to augmented cardiovascular [4] and cerebrovascular diseases, which are among the major health threats in Taiwan. The prevalence of high TC and high TG in Taiwan were previously estimated at $11.2 \%$ and $15.3 \%$, respectively [3]. In another study, age- and sex-specific hyperlipidemia patterns during 1991-2008 reportedly differed greatly among Taiwanese individuals [5]. 
Several factors ranging from genetic, environmental, and lifestyle factors are associated with hyperlipidemia. Some of its risk factors, such as excessive alcohol intake, smoking, high blood pressures, and others, can be controlled [6]. Secondary or acquired hyperlipidemia occurs frequently and is linked to diabetes, renal disease, and alcoholism [7]. Lifestyle habits and dietary changes are responsible for the increase in the prevalence of hyperlipidemia in Taiwan [5]. Of note, great efforts have been made to control the rate of hyperlipidemia. However, much still needs to be done, especially in high-risk patients [3] since adequate management may serve as an important step to reduce the risk of other conditions linked to hyperlipidemia, such as Alzheimer's disease [8].

Genetic mutations in several genes play a significant role in the development of hyperlipidemia [9]. Effects of genetic factors on hyperlipidemia may be direct or indirect in that, they may be mediated either by other genetic factors or by environmental and lifestyle choices. The low-density lipoprotein receptor (LDLR) gene is one of those genes that play an important role in maintaining cellular cholesterol homeostasis $[10,11]$. Several mutations in this gene have been reported to influence exons, splicing sites, and the promoter regions [11], and have also been recognized as a primary cause for familial hypercholesterolemia [12], a condition that has been associated with defective LDL uptake and degradation [4]. Besides, these mutations account for most of the cases with atherosclerosis and coronary heart diseases. One of the LDLR variants, rs688, has shown significant associations with coronary heart disease [13] as well as with higher plasma cholesterol levels (approximately $4 \%-10 \%$ ) in different populations [12,14-18]. Furthermore, the rs688 T/T genotype has shown associations with hyperlipidemia [11] and Alzheimer's disease [19] in a sex-dependent manner. Moreover, it was reportedly associated with higher total and LDL-cholesterol, particularly in pre-menopausal women [12]. Despite these findings, there are no compelling data on the sex-dependent association of rs688 with hyperlipidemia, particularly in Taiwan. Therefore, we evaluated the relationship between rs688 and hyperlipidemia in Taiwanese men and women aged 30-70 years.

\section{Methods}

\subsection{Study Population and Data Source}

The sample consisted of participants who were recruited from 2008 to 2015 into the Taiwan Biobank and whose baseline information was linked to the National Health Insurance Research databases (NHIRD) using encrypted personal identification numbers. Ethical approval was obtained from the Institutional Review Board of Chung Shan Medical University (CS2-16114).

Of the 17,985 biobank participants aged 30-70 years, we excluded those with incomplete information $(n=54)$ or missing genetic information $(n=4)$. The final analytic sample included 5416 cases with hyperlipidemia and 12,511 controls individuals.

\subsection{Definition of Variables}

The diagnosis coding in the NHIRD was based on ICD-9 codes. We identified patients with hyperlipidemia (ICD-9-CM: 272), diabetes mellitus (ICD-9-CM: 250), and hypertension (ICD-9-CM: 401-405) who must have had either two outpatient visits or one admission from 1998 to 2015. Alcohol drinkers were defined as persons who reported drinking more than $150 \mathrm{~mL}$ of alcohol per week for more than six months. Former drinkers included adults who drank in their lifetime but who had abstained from drinking for over 6 months. Smokers were defined as people who smoked continuously for more than six months. Never smokers included adults who never smoked or did not continuously smoke for 6 months or more while former smokers included those who smoked in their lifetime but who had not smoked in the last 6 months. The body-mass index (BMI) was calculated as weight in kilograms divided by height in meters squared $\left(\mathrm{kg} / \mathrm{m}^{2}\right)$. The TC/HDL was obtained by dividing total cholesterol by HDL cholesterol. 


\subsection{Selection of Single Nucleotide Polymorphism}

LDLR rs688 was selected based on a literature search. We restricted to this variant because of its significant associations with plasma cholesterol in different populations as cited above. Genotyping in the Taiwan Biobank was performed by Affymetrix using the Axiom ${ }^{\mathrm{TM}}$ Genome-Wide Array Plate System (Affymetrix, Santa Clara, CA, USA). Following the Taiwan Biobank (TWB) quality control, we excluded SNPs with low call rates $(<95 \%)$ and those that deviated from the Hardy-Weinberg equilibrium (that is, $p<1.0 \times 10^{-3}$ ). We further excluded those with minor allele frequency $<0.05$.

\subsection{Statistical Analysis}

Chi-square tests were used to compare the differences between the discrete variables. Logistic regression analysis was used to investigate the effects of sex and LDLR (rs688) gene variants on hyperlipidemia. The odds ratios (ORs) with their 95\% confidence intervals were estimated. Statistical analyses were performed using Statistical Analysis System (SAS) software (version 9.4) and PLINK 1.09 beta.

\section{Results}

Table 1 shows the descriptive data by gender. A total of $27.92 \%$ of the 9237 female participants and $32.65 \%$ of the 8690 male participants were identified with hyperlipidemia. The age groups differed significantly in men and women $(p<0.005)$. Compared to the C/C genotype, C/T and T/T genotypes were not significant risk factors for hyperlipidemia (OR = 1.061, CI: 0.976-1.153 for the $\mathrm{C} / \mathrm{T}$ and $\mathrm{OR}=1.052, \mathrm{CI}: 0.845-1.309$ for the T/T genotype) in the general model, as shown in Table 2. Compared to women, the odds ratio of hyperlipidemia in men was 0.919 (0.837-1.009). Age was a significant risk factor for hyperlipidemia. The ORs were 1.935 (CI: 1.697-2.207) in the 40-49 age group, 3.975 (CI: 3.495-4.520) in the 50-59 age group, and 6.123 (CI: 5.333-7.030) in the 60-70 age group, respectively; also associated with a higher risk of hyperlipidemia was overweight (OR, 1.281, CI: 1.168-1.404), obesity (OR, 1.557, CI: 1.401-1.730), diabetes (OR, 5.696, CI: 5.099-6.363), hypertension (OR, 3.352, CI: 3.069-3.662), and TC/HDL $\geq 5$ (OR, 1.897, CI: 1.702-2.114). There was a significant interaction between sex and rs6888 on hyperlipidemia risk ( $\mathrm{p}$-interaction $=0.0321$ ). Compared to females, the ORs for hyperlipidemia in C/C, C/T, and T/T male carriers was 0.936 (CI: 0.835-1.048), 0.940 (CI: 0.794-1.113), and 0.513 (0.29-0.907), as shown in Table 3. Older age, diabetes, and hypertension remained a significant risk factor no matter the genotype. The association of hyperlipidemia with rs688 genotypes was determined based on sex (Table 4). After stratification by sex, a significant OR was observed only in females with the T/T genotype (OR, 1.357, CI: 1.004-1.835). With the male sex/CC genotype as the reference group (Table 5), only the female sex/CT and T/T genotypes were associated with a significant risk of hyperlipidemia, with respective ORs of 1.153 (CI: 1.014-1.311) and 1.423 (CI: 1.056-1.917).

Table 1. Descriptive data of the participants by gender.

\begin{tabular}{cccccc}
\hline \multirow{2}{*}{ Variable } & \multicolumn{2}{c}{ Female } & \multicolumn{3}{c}{ Male } \\
\cline { 2 - 6 } & $\mathbf{N}$ & $\mathbf{\%}$ & $\mathbf{N}$ & $\mathbf{\%}$ & $p$-Value \\
\hline Hyperlipidemia & & & & & $<0.001$ \\
No & 6658 & 72.08 & 5853 & 67.35 & \\
Yes & 2579 & 27.92 & 2837 & 32.65 & \\
LDL (rs688) & & & & & 0.695 \\
CC & 6078 & 65.8 & 5733 & 65.97 & \\
CT & 2849 & 30.84 & 2685 & 30.90 & \\
TT & 310 & 3.36 & 272 & 3.13 & \\
Age & & & & & 0.005 \\
30-39 & 2385 & 25.82 & 2139 & 24.61 & \\
40-49 & 2502 & 27.09 & 2311 & 26.59 & \\
50-59 & 2513 & 27.21 & 2327 & 26.78 & \\
$60-70$ & 1837 & 19.89 & 1913 & 22.01 & \\
\hline
\end{tabular}


Table 1. Cont.

\begin{tabular}{|c|c|c|c|c|c|}
\hline \multirow{2}{*}{ Variable } & \multicolumn{2}{|c|}{ Female } & \multicolumn{2}{|c|}{ Male } & \multirow[b]{2}{*}{$p$-Value } \\
\hline & $\mathbf{N}$ & $\%$ & $\mathbf{N}$ & $\%$ & \\
\hline Elementary school & 713 & 7.72 & 323 & 3.72 & \\
\hline $\begin{array}{l}\text { Junior and Senior high } \\
\text { school }\end{array}$ & 4047 & 43.81 & 2942 & 33.86 & \\
\hline University above & 4477 & 48.47 & 5425 & 62.43 & \\
\hline Smoking & & & & & $<0.001$ \\
\hline Never & 8748 & 94.71 & 4769 & 51.63 & \\
\hline Former & 226 & 2.45 & 2079 & 22.51 & \\
\hline Current & 263 & 2.85 & 1842 & 19.94 & \\
\hline Alcohol drinking & & & & & $<0.001$ \\
\hline Never & 9006 & 97.50 & 7049 & 76.31 & \\
\hline Former & 70 & 0.76 & 461 & 4.99 & \\
\hline Current & 161 & 1.74 & 1180 & 12.77 & \\
\hline $\operatorname{BMI}\left(\mathrm{kg} / \mathrm{m}^{2}\right)$ & & & & & $<0.001$ \\
\hline $\mathrm{BMI}<18.5$ & 410 & 4.44 & 119 & 1.37 & \\
\hline $18.5 \leq \mathrm{BMI}<24$ & 5380 & 58.24 & 3232 & 37.19 & \\
\hline $24 \leq \mathrm{BMI}<27$ & 2037 & 22.05 & 3136 & 36.09 & \\
\hline $\mathrm{BMI} \geq 27$ & 1410 & 15.26 & 2203 & 25.35 & \\
\hline Diabetes & & & & & $<0.001$ \\
\hline No & 8064 & 87.30 & 7419 & 85.37 & \\
\hline Yes & 1173 & 12.70 & 1271 & 14.63 & \\
\hline Hypertension & & & & & $<0.001$ \\
\hline No & 7478 & 80.96 & 6236 & 71.76 & \\
\hline Yes & 1759 & 19.04 & 2454 & 28.24 & \\
\hline TC/HDL (ratio) & & & & & $<0.001$ \\
\hline$<5$ & 8587 & 92.96 & 6910 & 79.52 & \\
\hline$\geq 5$ & 650 & 7.04 & 1780 & 20.48 & \\
\hline
\end{tabular}

Table 2. Odds ratios for hyperlipidemia in the study participants.

\begin{tabular}{|c|c|c|c|}
\hline Variable & OR & $95 \% \mathrm{CI}$ & $p$-Value \\
\hline \multicolumn{4}{|l|}{ rs688 (ref: CC) } \\
\hline $\mathrm{CT}$ & 1.061 & $0.976-1.153$ & 0.162 \\
\hline TT & 1.052 & 0.845-1.309 & 0.651 \\
\hline \multicolumn{4}{|l|}{ Sex (ref: Female) } \\
\hline Male & 0.919 & $0.837-1.009$ & 0.075 \\
\hline \multicolumn{4}{|l|}{ Age (ref: 30-39) } \\
\hline $40-49$ & 1.935 & $1.697-2.207$ & $<0.001$ \\
\hline $50-59$ & 3.975 & $3.495-4.520$ & $<0.001$ \\
\hline $60-70$ & 6.123 & $5.333-7.030$ & $<0.001$ \\
\hline \multicolumn{4}{|l|}{$\begin{array}{l}\text { Education (ref: Elementary } \\
\text { school) }\end{array}$} \\
\hline $\begin{array}{l}\text { Junior and Senior high } \\
\text { school }\end{array}$ & 0.933 & $0.795-1.094$ & 0.391 \\
\hline University above & 0.997 & $0.848-1.172$ & 0.968 \\
\hline \multicolumn{4}{|l|}{ Smoking (ref: Never) } \\
\hline Former & 1.021 & $0.902-1.155$ & 0.746 \\
\hline Current & 0.943 & $0.823-1.081$ & 0.400 \\
\hline \multicolumn{4}{|l|}{$\begin{array}{c}\text { Alcohol drinking (ref: } \\
\text { Never) }\end{array}$} \\
\hline Former & 1.023 & $0.824-1.271$ & 0.834 \\
\hline Current & 1.016 & $0.871-1.184$ & 0.844 \\
\hline \multicolumn{4}{|l|}{ BMI (ref: $18.5 \leq \mathrm{BMI}<24$ ) } \\
\hline $\mathrm{BMI}<18.5$ & 0.661 & $0.493-0.885$ & 0.006 \\
\hline $24 \leq \mathrm{BMI}<27$ & 1.281 & $1.168-1.404$ & $<0.001$ \\
\hline $\mathrm{BMI} \geq 27$ & 1.557 & $1.401-1.730$ & $<0.001$ \\
\hline \multicolumn{4}{|l|}{ Diabetes (ref: No) } \\
\hline Yes & 5.696 & $5.099-6.363$ & $<0.001$ \\
\hline Hypertension (ref: No) & & & \\
\hline Yes & 3.352 & $3.069-3.662$ & $<0.001$ \\
\hline TC/HDL (ratio) (ref: <5) & & & \\
\hline$\geq 5$ & 1.897 & $1.702-2.114$ & $<0.001$ \\
\hline
\end{tabular}

BMI: Body-mass index (measured in $\mathrm{Kg} / \mathrm{m}^{2}$ ); TC: Total cholesterol; HDL-C: High-density lipoprotein cholesterol; OR: Odds ratio; CI: Confidence interval. 
Table 3. Odds ratios for hyperlipidemia based on rs688 genotypes.

\begin{tabular}{|c|c|c|c|c|c|c|}
\hline \multirow{3}{*}{ Variable } & \multicolumn{2}{|c|}{ rs688 (CC) } & \multicolumn{2}{|c|}{ rs688 (CT) } & \multicolumn{2}{|c|}{ rs688 (TT) } \\
\hline & \multicolumn{2}{|c|}{$\mathrm{N}=11,811$} & \multicolumn{2}{|c|}{$N=5534$} & \multicolumn{2}{|c|}{$N=582$} \\
\hline & OR & $95 \% \mathrm{CI}$ & OR & $95 \% \mathrm{CI}$ & OR & $95 \% \mathrm{CI}$ \\
\hline \multicolumn{7}{|l|}{ Sex (ref: Female) } \\
\hline Male & 0.936 & $0.835-1.048$ & 0.940 & $0.794-1.113$ & 0.513 & $0.29-0.907$ \\
\hline \multicolumn{7}{|l|}{ Age (ref: 30-39) } \\
\hline $40-49$ & 1.925 & $1.638-2.262$ & 1.912 & $1.508-2.426$ & 2.346 & $1.093-5.032$ \\
\hline $50-59$ & 3.824 & $3.264-4.481$ & 4.311 & $3.422-5.431$ & 3.732 & $1.745-7.981$ \\
\hline $60-70$ & 5.880 & $4.960-6.970$ & 6.430 & $5.015-8.244$ & 8.782 & $3.911-19.722$ \\
\hline \multicolumn{7}{|l|}{ Education (ref: Elementary school) } \\
\hline Junior and Senior high school & 0.970 & $0.797-1.180$ & 0.875 & $0.654-1.170$ & 1.000 & $0.434-2.301$ \\
\hline University above & 1.006 & $0.824-1.227$ & 1.006 & $0.748-1.353$ & 0.873 & $0.366-2.083$ \\
\hline \multicolumn{7}{|l|}{ Smoking (ref: Never) } \\
\hline Former & 1.080 & $0.928-1.256$ & 0.879 & $0.702-1.102$ & 1.195 & $0.544-2.624$ \\
\hline Current & 0.975 & $0.826-1.151$ & 0.856 & $0.665-1.101$ & 0.966 & $0.433-2.156$ \\
\hline \multicolumn{7}{|l|}{ Alcohol drinking (ref: Never) } \\
\hline Former & 1.041 & $0.794-1.366$ & 1.108 & $0.758-1.620$ & 0.456 & $0.124-1.683$ \\
\hline Current & 1.072 & $0.890-1.292$ & 0.844 & $0.633-1.125$ & 2.115 & $0.848-5.278$ \\
\hline \multicolumn{7}{|l|}{ BMI (ref: $18.5 \leq \mathrm{BMI}<24$ ) } \\
\hline $\mathrm{BMI}<18.5$ & 0.634 & $0.436-0.921$ & 0.671 & $0.404-1.113$ & 1.358 & $0.366-5.040$ \\
\hline $24 \leq \mathrm{BMI}<27$ & 1.267 & $1.131-1.419$ & 1.378 & $1.168-1.626$ & 0.740 & $0.421-1.302$ \\
\hline $\mathrm{BMI} \geq 27$ & 1.518 & $1.335-1.727$ & 1.646 & $1.358-1.995$ & 1.732 & $0.924-3.245$ \\
\hline \multicolumn{7}{|l|}{ Diabetes (ref: No) } \\
\hline \multirow{2}{*}{\multicolumn{7}{|c|}{$\begin{array}{c}\text { Yes } \\
\text { Hypertension (ref: No) }\end{array}$}} \\
\hline & & & & & & \\
\hline Yes & 3.402 & $3.051-3.792$ & 3.310 & $2.823-3.880$ & 2.854 & $1.658-4.912$ \\
\hline \multicolumn{7}{|l|}{ TC/HDL (ratio) (ref: <5) } \\
\hline$\geq 5$ & 1.957 & $1.712-2.236$ & 1.757 & $1.447-2.134$ & 2.519 & $1.318-4.815$ \\
\hline
\end{tabular}

BMI: Body-mass index (measured in Kg/m²); TC: Total cholesterol; HDL-C: High-density lipoprotein cholesterol; OR: Odds ratio; CI: Confidence interval. 
Table 4. Odds ratio for hyperlipidemia based on gender.

\begin{tabular}{|c|c|c|c|c|}
\hline \multirow{3}{*}{ Variable } & \multicolumn{2}{|c|}{ Female } & \multicolumn{2}{|c|}{ Male } \\
\hline & \multicolumn{2}{|c|}{$\mathrm{N}=9237$} & \multicolumn{2}{|c|}{$\mathrm{N}=8690$} \\
\hline & OR & $95 \% \mathrm{CI}$ & OR & $95 \% \mathrm{CI}$ \\
\hline \multicolumn{5}{|l|}{ rs688 (ref: CC) } \\
\hline $\mathrm{CT}$ & 1.105 & $0.980-1.247$ & 1.015 & $0.904-1.139$ \\
\hline TT & 1.357 & $1.004-1.835$ & 0.798 & $0.579-1.100$ \\
\hline \multicolumn{5}{|l|}{ Age (ref: 30-39) } \\
\hline $40-49$ & 2.024 & $1.649-2.484$ & 1.877 & $1.578-2.234$ \\
\hline $50-59$ & 5.062 & $4.158-6.163$ & 3.215 & $2.702-3.825$ \\
\hline $60-70$ & 10.287 & $8.343-12.684$ & 3.811 & $3.158-4.600$ \\
\hline \multicolumn{5}{|l|}{$\begin{array}{l}\text { Education (ref: Elementary } \\
\text { school) }\end{array}$} \\
\hline Junior and Senior high school & 0.875 & $0.717-1.067$ & 1.220 & $0.926-1.608$ \\
\hline University above & 0.900 & $0.732-1.108$ & 1.355 & $1.031-1.780$ \\
\hline \multicolumn{5}{|l|}{ Smoking (ref: Never) } \\
\hline Former & 0.889 & $0.590-1.342$ & 1.076 & $0.944-1.226$ \\
\hline Current & 1.256 & $0.888-1.778$ & 0.887 & $0.765-1.028$ \\
\hline \multicolumn{5}{|l|}{ Alcohol drinking (ref: Never) } \\
\hline Former & 1.331 & $0.741-2.388$ & 1.019 & $0.809-1.282$ \\
\hline Current & 1.025 & $0.650-1.615$ & 1.021 & $0.868-1.201$ \\
\hline \multicolumn{5}{|l|}{ BMI (ref: $18.5 \leq$ BMI < 24) } \\
\hline $\mathrm{BMI}<18.5$ & 0.739 & $0.527-1.037$ & 0.476 & $0.254-0.893$ \\
\hline $24 \leq \mathrm{BMI}<27$ & 1.242 & $1.084-1.422$ & 1.273 & $1.120-1.446$ \\
\hline $\mathrm{BMI} \geq 27$ & 1.562 & $1.333-1.831$ & 1.483 & $1.283-1.713$ \\
\hline \multicolumn{5}{|l|}{ Diabetes (ref: No) } \\
\hline Yes & 5.984 & $5.089-7.035$ & 5.621 & $4.819-6.556$ \\
\hline Hypertension (ref: No) & & & & \\
\hline $\begin{array}{c}\text { Yes } \\
\text { TC/HDL (ratio) (ref: <5) }\end{array}$ & 2.979 & $2.605-3.408$ & 3.720 & $3.306-4.186$ \\
\hline$\geq 5$ & 1.926 & $1.587-2.338$ & 1.805 & $1.584-2.057$ \\
\hline
\end{tabular}

BMI: Body-mass index (measured in $\mathrm{Kg} / \mathrm{m}^{2}$ ); TC: Total cholesterol; HDL-C: High-density lipoprotein cholesterol; OR: Odds ratio; CI: Confidence interval.

Table 5. Odds ratio for hyperlipidemia according to gender and rs688 genotypes.

\begin{tabular}{|c|c|c|}
\hline Variable & OR & $95 \% \mathrm{CI}$ \\
\hline \multicolumn{3}{|c|}{ Sex and rs688 genotype (ref: Male and CC) } \\
\hline Male and CT & 1.017 & $0.905-1.144$ \\
\hline Male and TT & 0.779 & $0.562-1.08$ \\
\hline Female and CC & 1.041 & $0.935-1.16$ \\
\hline Female and CT & 1.153 & $1.014-1.311$ \\
\hline Female and TT & 1.423 & $1.056-1.917$ \\
\hline \multicolumn{3}{|l|}{ Age (ref: $30-39$ ) } \\
\hline $40-49$ & 1.936 & $1.697-2.208$ \\
\hline $50-59$ & 3.971 & $3.492-4.515$ \\
\hline $60-70$ & 6.128 & $5.337-7.035$ \\
\hline \multicolumn{3}{|l|}{ Education (ref: Elementary school) } \\
\hline Junior and Senior high school & 0.935 & $0.797-1.096$ \\
\hline University above & 0.998 & $0.849-1.174$ \\
\hline \multicolumn{3}{|l|}{ Smoking (ref: Never) } \\
\hline Former & 1.022 & $0.903-1.156$ \\
\hline Current & 0.943 & $0.823-1.080$ \\
\hline \multicolumn{3}{|l|}{ Alcohol drinking (ref: Never) } \\
\hline Former & 1.027 & $0.827-1.275$ \\
\hline Current & 1.016 & $0.871-1.185$ \\
\hline \multicolumn{3}{|l|}{ BMI (ref:18.5 $\leq$ BMI $<24)$} \\
\hline $\mathrm{BMI}<18.5$ & 0.659 & $0.491-0.883$ \\
\hline $24 \leq \mathrm{BMI}<27$ & 1.281 & $1.168-1.404$ \\
\hline $\mathrm{BMI} \geq 27$ & 1.558 & $1.402-1.731$ \\
\hline \multicolumn{3}{|l|}{ Diabetes (ref: No) } \\
\hline Yes & 5.698 & $5.100-6.366$ \\
\hline Hypertension (ref: No) & & \\
\hline Yes & 3.352 & $3.068-3.661$ \\
\hline TC/HDL (ratio) (ref: <5) & & \\
\hline$\geq 5$ & 1.898 & $1.703-2.115$ \\
\hline
\end{tabular}

BMI: Body mass index (measured in $\mathrm{Kg} / \mathrm{m}^{2}$ ); TC: Total cholesterol; HDL-C: High-density lipoprotein cholesterol; OR: Odds ratio; CI: Confidence interval. 


\section{Discussion}

In this study, we evaluated the relationship between rs688 and hyperlipidemia in Taiwanese men and women aged 30-70 years. Our preliminary results showed that of the overall samples, rs688 C/T and $\mathrm{T} / \mathrm{T}$ genotypes did not show significant associations with hyperlipidemia when $\mathrm{C} / \mathrm{C}$ genotype was used as the reference genotype. However, we detected an interaction between the rs688 polymorphism and sex on hyperlipidemia ( $p$-interaction $=0.0321$ ). Across the three rs688 genotypes, we found significant associations only among rs688 $\mathrm{T} / \mathrm{T}$ male carriers; that is, the OR for hyperlipidemia was significant only in T/T (OR, 0.5, CI: 0.29-0.907) but not C/T and CC carriers. It is not certain why the rs688 allele with the higher risk associated with hyperlipidemia was significantly lower in our male population. Nevertheless, this may be attributed to rs688 actions on splicing efficiency, which has been shown to significantly decrease in women compared to men [12]. Besides, the observed association may have been affected by other modulation factors. Nevertheless, more replication studies will be needed to support our findings. Of note, prior investigations in Taiwan have shown gender differences in hyperlipidemia, where the risk was relatively higher in men below 50 years of age, but lower in those over 50 years compared to their female counterparts [3]. However, genetic aspects of hyperlipidemia were not described.

According to findings from previous studies, the LDLR rs688 T/T genotype and $\mathrm{T}$ allele are associated with lipid traits [20,21] and heightened risk of coronary artery diseases [11,13]. Our data showed that the risk of hyperlipidemia was significantly lower in men with the T/T genotype as noted above. When men and women were analyzed separately, only $\mathrm{T} / \mathrm{T}$ women were found to have higher odds of hyperlipidemia. However, when the women and men were analyzed for the three rs688 genotypes, results indicated that $\mathrm{T} / \mathrm{T}$ and $\mathrm{C} / \mathrm{T}$ genotypes were significant risk factors in women. In a previous study, cholesterol values for $\mathrm{rs} 688 \mathrm{C} / \mathrm{T}$ and $\mathrm{T} / \mathrm{T}$ carriers were both significantly higher than the $\mathrm{C} / \mathrm{C}$ carriers, but not different from each other [12]. Associations have also been reported between the $\mathrm{T}$ allele of the rs688 polymorphism and elevated total and LDL-cholesterol, particularly in pre-menopausal women [11,12]. It has been established that the rs688 C/T allele would greatly alter LDLR exon 12 splicing efficiency in women, especially those considered to be menopausal [11]. This in part may be the reason why the $\mathrm{T}$ allele was the significant risk allele for hyperlipidemia among women in our study.

Previous findings by Guize and colleagues provided evidence that cholesterolemia is closely associated with age and sex [13]. Our study also provided additional information that hyperlipidemia risk increased with age no matter the rs688 genotype. The highest odds ratios occurred in individuals aged 60-70 years. However, also associated with hyperlipidemia was overweight, obesity, and hypertension. These findings share a number of similarities with those of Yin et al. [22], where hyperlipidemia was positively associated with the body-mass index and hypertension in middle-aged and elderly Han and Bai individuals. In contrast, they found no significant relationship between hyperlipidemia and age. However, in their study, stratifications were not made for age. We also demonstrated that hyperlipidemia was closely related to diabetes in all genotype carriers.

We acknowledge that our study may have some limitations. Cholesterolemia has reportedly decreased significantly in women beyond 70 . However, our study was restricted to participants aged $30-70$, hence we could not analyze data of those over 70 years of age. Second, response bias is a possibility since information was collected using questionnaires.

In conclusion, we demonstrated that there was an interaction between sex and rs6888 on hyperlipidemia risk. Our data indicate that the rs688 C/T and T/T genotypes may be associated with a higher risk of hyperlipidemia in Taiwanese women when compared to men with the $\mathrm{C} / \mathrm{C}$ genotype. This information may be used to optimize lipid-modification therapy, which may help to prevent atherosclerosis and its clinical manifestations in (but not limited to) these individuals.

Author Contributions: Conceptualization, Y.-T.L., O.N.N., L.W., S.-Y.H., C.-C.L., D.M.T., M.-C.W., H.-R.C. and Y.-P.L.; data curation, M.-C.W.; formal analysis, O.N.N. and S.-Y.H.; methodology, Y.-T.L., L.W., C.-C.L., D.M.T., H.-R.C. and Y.-P.L.; resources, Y.-P.L.; supervision, H.-R.C.; writing-original draft, Y.-T.L.; writing-review and 
editing, O.N.N., L.W., S.-Y.H., C.-C.L., D.M.T., M.-C.W., H.-R.C. and Y.-P.L. All authors have read and agreed to the published version of the manuscript.

Funding: Ministry of Science and Technology (MOST 105-2627-M-040-002; 106-2627-M-040-002; 107-2627-M-040-002 and 106 -EPA EPA-F-016-001).

Conflicts of Interest: The authors declare no conflict of interest. The funders had no role in the design of the study; in the collection, analyses, or interpretation of data; in the writing of the manuscript, or in the decision to publish the results.

\section{References}

1. Yu, Q.; Zhao, J.; Xu, Z.; Chen, Y.; Shao, T.; Long, X.; Liu, Z.; Gao, X.; Rengel, Z.; Shi, J. Inulin from Jerusalem artichoke tubers alleviates hyperlipidemia and increases abundance of bifidobacteria in the intestines of hyperlipidemic mice. J. Funct. Foods 2018, 40, 187-196. [CrossRef]

2. Pan, W.-H.; Wu, H.-J.; Yeh, C.-J.; Chuang, S.-Y.; Chang, H.-Y.; Yeh, N.-H.; Hsieh, Y.-T. Diet and health trends in Taiwan: comparison of two nutrition and health surveys from 1993-1996 and 2005-2008. Asia Pac. J. Clin. Nutr. 2011, 20, 238. [PubMed]

3. Lin, C.-F.; Chang, Y.-H.; Chien, S.-C.; Lin, Y.-H.; Yeh, H.-Y. Epidemiology of dyslipidemia in the Asia Pacific region. Int. J. Gerontol. 2018, 12, 2-6. [CrossRef]

4. Paththinige, H.C.; Sirisena, N.; Dissanayake, V. Genetic determinants of inherited susceptibility to hypercholesterolemia-a comprehensive literature review. Lipids Health Dis. 2017, 16, 103. [CrossRef] [PubMed]

5. $\quad$ Li, Y.-H.; Ueng, K.-C.; Jeng, J.-S.; Charng, M.-J.; Lin, T.-H.; Chien, K.-L.; Wang, C.-Y.; Chao, T.-H.; Liu, P.-Y.; $\mathrm{Su}, \mathrm{C} .-\mathrm{H} .2017$ Taiwan lipid guidelines for high risk patients. J. Formos. Med. Assoc. 2017, 116, 217-248. [CrossRef] [PubMed]

6. Fatima, N.; Chandra, T.; Mahdi, A.A.; Agarwal, D. Level of hyperlipidemia in blood donors: A correlative study in North Indian population. Diabetes Metab. Syndr. 2019, 13, 2033-2036. [CrossRef]

7. Nelson, R.H. Hyperlipidemia as a risk factor for cardiovascular disease. Prim. Care Clin. Off. Pract. 2013, 40, 195-211. [CrossRef]

8. Lim, S.-W.; Nyam, T.-T.E.; Ho, C.-H.; Shiue, Y.-L.; Wang, J.-J.; Chio, C.-C.; Kuo, J.-R. Increased Risk of Anxiety or Depression After Traumatic Spinal Cord Injury in Patients with Preexisting Hyperlipidemia: A Population-Based Study. World Neurosurg. 2017, 106, 402-408. [CrossRef]

9. Karr, S. Epidemiology and management of hyperlipidemia. Am. J. Manag. Care. 2017, 23, S139-S148.

10. Goldstein, J.L.; Anderson, R.; Brown, M.S. (Eds.) Receptor-mediated endocytosis and the cellular uptake of low density lipoprotein. Ciba Found. Symp. 1982. [CrossRef]

11. Jha, C.; Mir, R.; Khullar, N.; Banu, S.; Chahal, S. LDLR rs688 TT genotype and T allele are associated with increased susceptibility to coronary artery disease-A case-control study. J. Cardiovasc. Dev. Dis. 2018, 5, 31. [CrossRef] [PubMed]

12. Zhu, H.; Tucker, H.M.; Grear, K.E.; Simpson, J.F.; Manning, A.K.; Cupples, L.A.; Estus, S. A common polymorphism decreases low-density lipoprotein receptor exon 12 splicing efficiency and associates with increased cholesterol. Human Mol. Genet. 2007, 16, 1765-1772. [CrossRef] [PubMed]

13. Martinelli, N.; Girelli, D.; Lunghi, B.; Pinotti, M.; Marchetti, G.; Malerba, G.; Pignatti, P.F.; Corrocher, R.; Olivieri, O.; Bernardi, F. Polymorphisms at LDLR locus may be associated with coronary artery disease through modulation of coagulation factor VIII activity and independently from lipid profile. Blood J. Am. Soc. Hematol. 2010, 116, 5688-5697. [CrossRef] [PubMed]

14. Gao, F.; Ihn, H.E.; Medina, M.W.; Krauss, R.M. A common polymorphism in the LDL receptor gene has multiple effects on LDL receptor function. Human Mol. Genet. 2013, 22, 1424-1431. [CrossRef]

15. Teslovich, T.M.; Musunuru, K.; Smith, A.V.; Edmondson, A.C.; Stylianou, I.M.; Koseki, M.; Pirruccello, J.P.; Ripatti, S.; Chasman, D.I.; Willer, C.J. Biological, clinical and population relevance of 95 loci for blood lipids. Nature 2010, 466, 707. [CrossRef]

16. Fu, Y.; Katsuya, T.; Higaki, J.; Asai, T.; Fukuda, M.; Takiuchi, S.; Hatanaka, Y.; Rakugi, H.; Ogihara, T. A common mutation of low-density lipoprotein receptor gene is associated with essential hypertension among Japanese. J. Hum. Hypertens. 2001, 15, 125. [CrossRef] 
17. Schaefer, E.J.; Lamon-Fava, S.; Johnson, S.; Ordovas, J.M.; Schaefer, M.M.; Castelli, W.P.; Wilson, P. Effects of gender and menopausal status on the association of apolipoprotein E phenotype with plasma lipoprotein levels. Results from the Framingham Offspring Study. Arter. Thromb. 1994, 14, 1105-1113. [CrossRef]

18. Boright, A.P.; Connelly, P.W.; Brunt, J.H.; Morgan, K.; Hegele, R.A. Association and linkage of LDLR gene variation with variation in plasma low density lipoprotein cholesterol. J. Hum. Genet. 1998, 43, 153. [CrossRef]

19. Zou, F.; Gopalraj, R.K.; Lok, J.; Zhu, H.; Ling, I.-F.; Simpson, J.F.; Tucker, H.M.; Kelly, J.F.; Younkin, S.G.; Dickson, D.W. Sex-dependent association of a common low-density lipoprotein receptor polymorphism with RNA splicing efficiency in the brain and Alzheimer's disease. Hum. Mol. Genet. 2008, 17, 929-935. [CrossRef]

20. Park, M.-H.; Kim, N.; Lee, J.-Y.; Park, H.-Y. Genetic loci associated with lipid concentrations and cardiovascular risk factors in the Korean population. J. Med. Genet. 2011, 48, 10-15. [CrossRef]

21. Lu, Y.; Feskens, E.J.; Boer, J.M.; Imholz, S.; Verschuren, W.M.; Wijmenga, C.; Vaarhorst, A.; Slagboom, E.; Müller, M.; Dollé, M.E. Exploring genetic determinants of plasma total cholesterol levels and their predictive value in a longitudinal study. Atherosclerosis 2010, 213, 200-205. [CrossRef] [PubMed]

22. Ruixing, Y.; Jinzhen, W.; Yaoheng, H.; Jing, T.; Hai, W.; Muyan, L.; Yiyang, L.; Dongmei, F.; Hanjun, Y.; Yuming, C. Associations of diet and lifestyle with hyperlipidemia for middle-aged and elderly persons among the Guangxi Bai Ku Yao and Han populations. J. Am. Diet. Assoc. 2008, 108, 970-976. [CrossRef] [PubMed]

(C) 2020 by the authors. Licensee MDPI, Basel, Switzerland. This article is an open access article distributed under the terms and conditions of the Creative Commons Attribution (CC BY) license (http://creativecommons.org/licenses/by/4.0/). 